\title{
pH-Dependent Degradation of T3P-Related \\ Byproducts
}

\author{
Andrew Davidson ${ }^{\dagger}$, David A. Foley ${ }^{\dagger}$, Heather Frericks-Schmidt, ${ }^{*}$ Sally Gut Ruggeri, Madeline \\ Herman, Shawn LaCasse, Yizhou Liu ${ }^{\dagger}$ Emma L. McInturff*, Ronald Morris, ${ }^{\dagger}$ Naila Mugheirbi, \\ Brian Samas, ${ }^{\ddagger}$ Aritra Sarkar ${ }^{\dagger}$ Robert A. Singer, Faith Witkos ${ }^{\ddagger}$ Shu Yu
}

\section{Supporting Information}

1. Experimental details for Powder X-ray characterization

2. Details for Flow NMR experiments

2.1. Flow NMR experiments under acidic and basic conditions

2.1.1. Overlay of ${ }^{31} \mathrm{P}$ NMR at $\mathrm{pH} 4.9-13.4$ and temperature $25-80{ }^{\circ} \mathrm{C}$

2.2. Kinetic Flow NMR experiment for the conversion of $\mathbf{2}$ to $\mathbf{3}$

2.2.1. Kinetic profile for the conversion of 2 to 3 at $\mathrm{pH} 0.76$ and $70{ }^{\circ} \mathrm{C}$.

3. Characterization of $2 \cdot 2 \mathrm{Na}^{+}$

4. Characterization of $\mathbf{3}$ by comparison with propylphosphonic acid

5. Effect of crown ether on 2

6. Variable temperature NMR study

7. Computational analysis of 2

8. Characterization of $\mathbf{9}$ and $\mathbf{1 0}$ (from reaction mixture)

9. Tabulated data of degradation of $\mathbf{9}$ and $\mathbf{1 0}$ to form $\mathbf{6}$ 


\section{Experimental details for Powder X-ray characterization}

Powder X-ray characterization was carried out using a Bruker AXS D8 Endeavor diffractometer. Monochromatic $\mathrm{Cu} \mathrm{Ka}$ radiation, with a voltage of $40 \mathrm{kV}$ and a current of $40 \mathrm{~mA}$, was used as the $\mathrm{X}$-ray source. Samples were prepared by placing them in a silicon low background sample holder, pressed smooth and rotated during collection. Data were collected using Bruker DIFFRAC Plus software and analysis was performed by EVA diffract plus software. Data was collected in the Theta-Theta goniometer at the $\mathrm{Cu}$ wavelength from 3.0 to 40.0 degrees 2-Theta using a step size of 0.016 degrees and a step time of 0.3 second. The calculated powder pattern was obtained by analyzing the CIF file using Mercury 5.4 software. 


\section{Details for Flow NMR experiments}

\subsection{Flow NMR experiments under acidic and basic conditions}

Compound $2 \cdot 2 \mathrm{Na}^{+}(205 \mathrm{mg}, 0.89 \mathrm{mmol})$ was added to a $50 \mathrm{~mL}$ EasyMax vessel and was then dissolved in water $(23 \mathrm{~mL})$. The solution temperature was set at $25^{\circ} \mathrm{C}$, and was circulated (flow rate $2 \mathrm{~mL} / \mathrm{min}$ ) through the flow $\mathrm{NMR}$ tube system at a flow rate of $2 \mathrm{~mL} / \mathrm{min} .{ }^{31} \mathrm{P}$ NMR spectra were acquired with proton decoupling (pulse sequence: zgpg30, 64 scans and 2 sec relaxation delay). NMR spectra were recorded on a Bruker Avance III NMR spectrometer operating at 400 $\mathrm{MHz}$, equipped with $5 \mathrm{~mm}$ BBFO (broadband flourine observe) probe tuned to ${ }^{31} \mathrm{P}$ nucleus at 161.97 MHz.

The $\mathrm{pH}$ of the solution was adjusted using:

1. High $\mathrm{pH}$ experiment: $1 \mathrm{~N} \mathrm{NaOH}$ until $\mathrm{pH} 12.7$ and then using solid $\mathrm{NaOH}$ pellets to higher $\mathrm{pH}$ values.

2. Low $\mathrm{pH}$ experiment: conc. $\mathrm{HCl}$.

The $\mathrm{pH}$ was monitored using a calibrated $\mathrm{pH}$ meter (Thermo Scientific Orion Star A211).

2.1.1 Overlay of ${ }^{31} \mathrm{P}$ NMR at $\mathrm{pH} 4.9-13.4$ and temperature $25-80{ }^{\circ} \mathrm{C}$, showing no degradation of 2 (likely existing as bis-sodium salt).

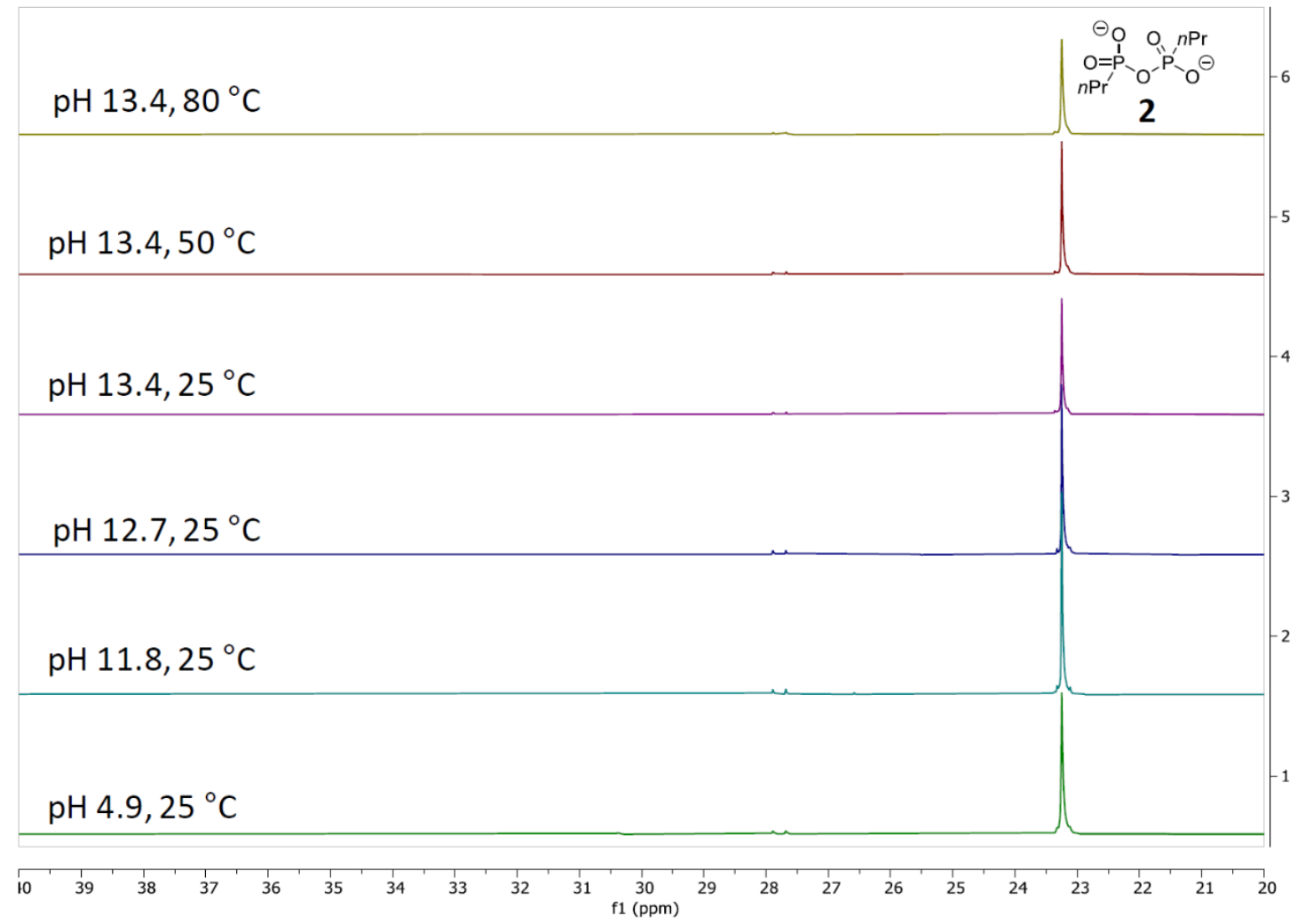




\subsection{Kinetic Flow NMR experiment for the conversion of 2 to 3}

The kinetic experiment was conducted using the same experimental conditions as described above. The $\mathrm{pH}$ of the reaction mixture was adjusted to $\mathrm{pH} 0.76$ using conc. $\mathrm{HCl}$. The temperature of the reaction vessel was heated to $70{ }^{\circ} \mathrm{C}$ and the reaction mixture circulated through the flow NMR tube system at $2 \mathrm{~mL} / \mathrm{min} .{ }^{31} \mathrm{P}$ NMR spectra were acquired at 15 minute intervals on the constantly circulating reaction solution.

\subsubsection{Kinetic profile for the conversion of 2 to 3 at $\mathrm{pH} 0.76$ and $70{ }^{\circ} \mathrm{C}$.}

\section{$\mathrm{pH}$ adjustment at $70^{\circ} \mathrm{C}$}

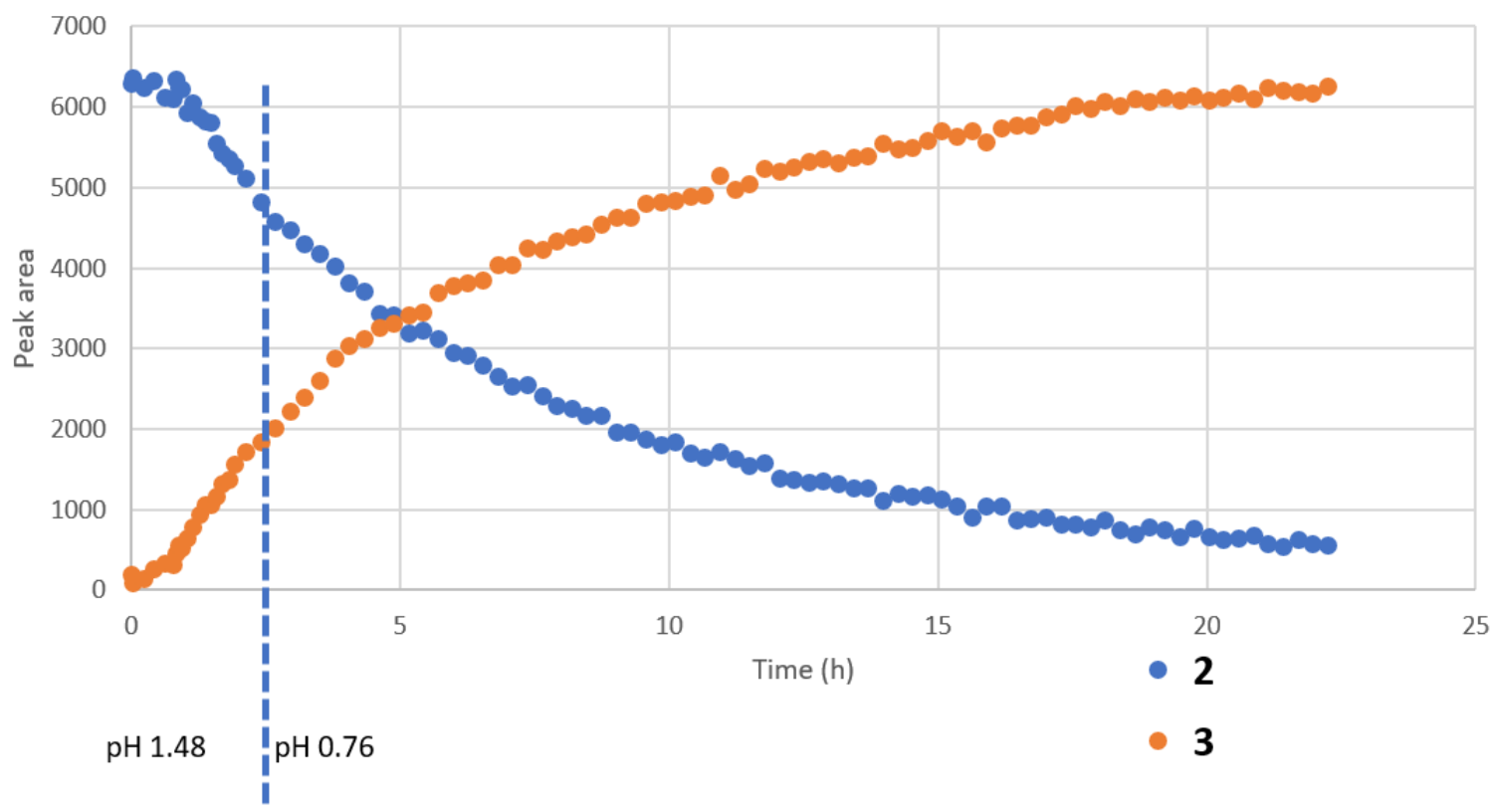

Note: The monomeric propyl phosphonate is likely protonated under these conditions and exists as propylphosphonic acid. 


\section{Characterization of $2 \cdot 2 \mathrm{Na}^{+}$}

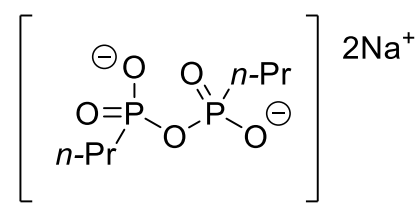

\section{MS characterization}

Mass spectrometry data was collected using Bruker Solarix XR 7T FTICR using the following conditions:

Spray Voltage: $3500 \mathrm{~V}$

Nebulizer gas:1. bar

Dry gas: $31 / \mathrm{min}$

Dry temp: $200 \mathrm{C}$

TOF:0.7

Scan Range:129-2000 Daltons full scan

Resolving Power: $90000 @$ m/z 400

The sample was dissolved in 9:1 0.1\% formic acid/acetonitrile and infused at $120 \mu \mathrm{L} / \mathrm{h}$.

Calculated for $\mathrm{C}_{6} \mathrm{H}_{15} \mathrm{O}_{5} \mathrm{P}_{2}: 229.04002$ Observed: 229.04007

\section{NMR characterization}

${ }^{1} \mathrm{H}$ NMR $\left(\mathrm{D}_{2} \mathrm{O}, 600 \mathrm{MHz}\right): \delta_{\mathrm{H}} 1.53-1.69\left(4 \mathrm{H}, \mathrm{m}, \mathrm{CH}_{2} \mathrm{CH}_{2} \mathrm{CH}_{3}\right), 1.40-1.53\left(4 \mathrm{H}, \mathrm{m}, \mathrm{CH}_{2} \mathrm{CH}_{2} \mathrm{CH}_{3}\right)$, $0.89\left(6 \mathrm{H}, \mathrm{t}, J=7.3 \mathrm{~Hz}, \mathrm{CH}_{3}\right) .{ }^{13} \mathrm{C}\left\{{ }^{1} \mathrm{H}\right\} \mathrm{NMR}\left(\mathrm{D}_{2} \mathrm{O}, 150 \mathrm{MHz}\right): \delta_{\mathrm{C}} 30.6\left(\mathrm{~m}, \underline{\mathrm{CH}}_{2} \mathrm{CH}_{2} \mathrm{CH}_{3}\right.$, virtual coupling effect of an AXX' spin system, ${ }^{1} J_{\mathrm{CP}}=137.0 \mathrm{~Hz},{ }^{2} J_{\mathrm{PP}}=30.0 \mathrm{~Hz}$, coupling constants obtained through spectral simulation), 16.6 ( $\mathrm{m}, \mathrm{CH}_{2} \mathrm{CH}_{2} \mathrm{CH}_{3}$, virtual coupling effect of an AXX' spin system, ${ }^{2} J_{\mathrm{CP}}=5.0 \mathrm{~Hz},{ }^{2} J_{\mathrm{PP}}=30.0 \mathrm{~Hz}$, coupling constants obtained through spectral simulation), 15.0 (m, $\underline{\mathrm{H}}_{3}$, virtual coupling effect of an $\mathrm{AXX}$ ' spin system, ${ }^{3} J_{\mathrm{CP}}=18.4 \mathrm{~Hz},{ }^{2} J_{\mathrm{PP}}=$ $30.0 \mathrm{~Hz}$, coupling constants obtained through spectral simulation). ${ }^{31} \mathrm{P}\left\{{ }^{1} \mathrm{H}\right\} \mathrm{NMR}\left(\mathrm{D}_{2} \mathrm{O}, 243\right.$ MHz): $\delta$ P 19.7 (s). 
00712555-0066_SEG2019-264_precipitant-rxn-filter.8.fid

H1, Bruker600M BBFO

$10.9 \mathrm{mg}$ dissolved in $155 \mathrm{uL}$ D2O

$25 \mathrm{C}$ 这

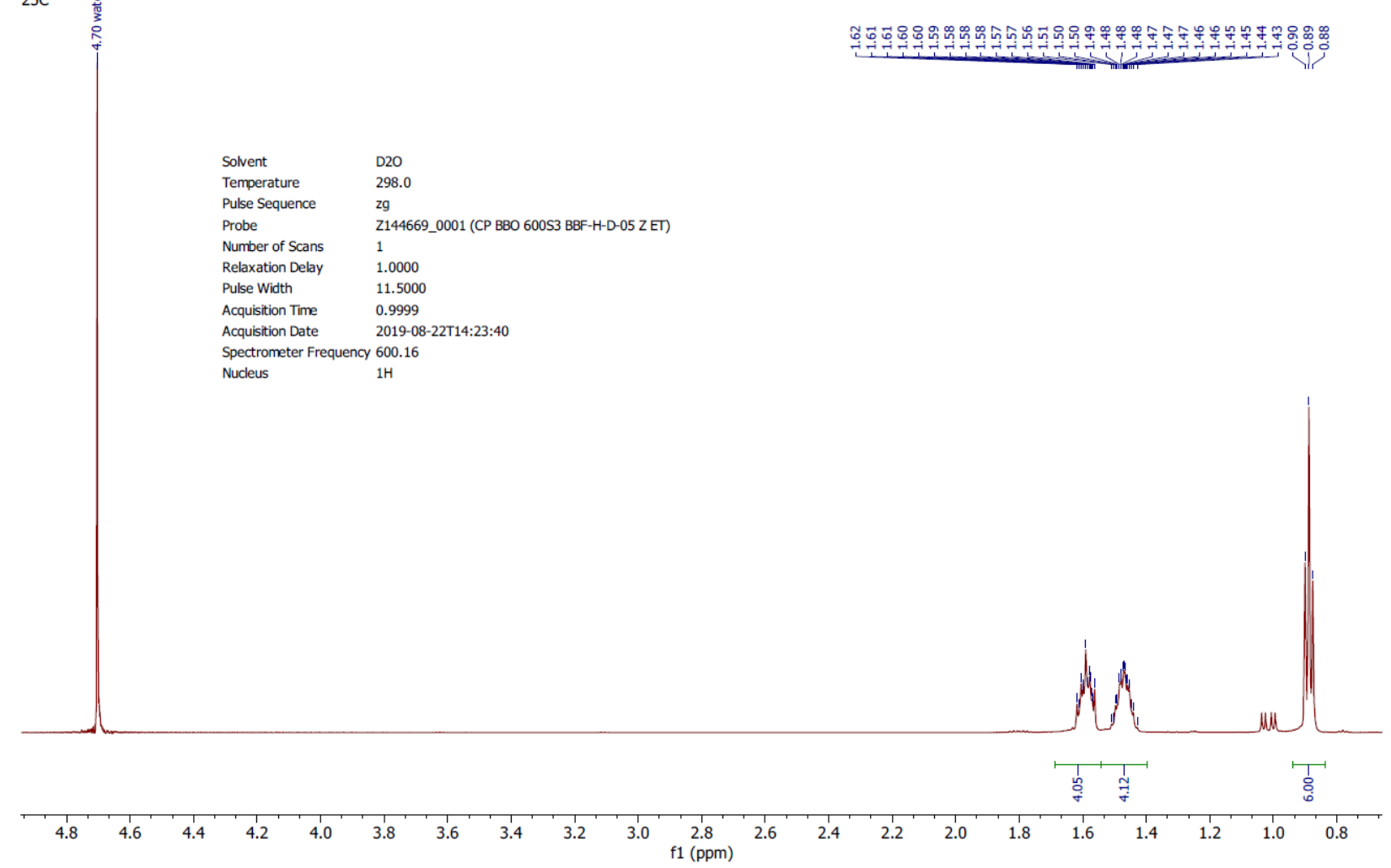

${ }^{1} \mathrm{H}$ spectrum $\left(600 \mathrm{MHz}, \mathrm{D}_{2} \mathrm{O}\right)$ of 2 collected at $298 \mathrm{~K}$ on a Bruker AVANCE II spectrometer equipped with a liquid-helium cooled BBFO cryoprobe. 
00712555-0066_SEG2019-264_precipitant-rxn-filter.27.fid

C13, Bruker600M BBFO

$10.9 \mathrm{mg}$ dissolved in 155 uL D2O

$25 \mathrm{C}$ after 18 hours
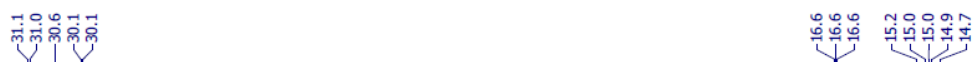

Solvent $\quad$ D20

Temperature $\quad 298.0$

Pulse Sequence zgpg30

Z144669_0001 (CP BBO 600S3 BBF-H-D-05 Z ET)

Nunber of Scans - 1024

Relaxation Delay $\quad 2.0000$

Pulse Width $\quad 10.0000$

Acquisition Time $\quad 0.9044$

Acquisition Date 2019-08-23T12:36:29

Spectrometer Frequency 150.92

Nudeus

$13 \mathrm{C}$

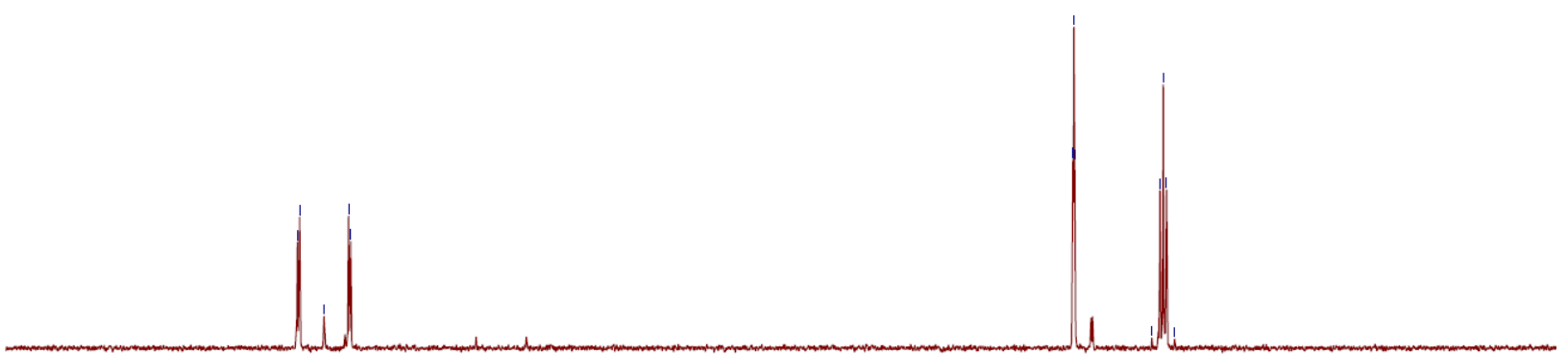

$\begin{array}{lllllllllllllllllllllllllllllllllll}36 & 35 & 34 & 33 & 32 & 31 & 30 & 29 & 28 & 27 & 26 & 25 & 24 & 23 & 22 & 21 & 20 & 19 & 18 & 17 & 16 & 15 & 14 & 13 & 12 & 11 & 10 & 9 & 8\end{array}$

${ }^{13} \mathrm{C}\left\{{ }^{1} \mathrm{H}\right\}$ spectrum $\left(150 \mathrm{MHz}, \mathrm{D}_{2} \mathrm{O}\right)$ of 2 collected at $298 \mathrm{~K}$ on a Bruker AVANCE II spectrometer equipped with a liquid-helium cooled BBFO cryoprobe. 
00712555-0066_SEG2019-264_precipitant-rxn-filter.9.fid

31 Bruker $600 \mathrm{MHz}$ BBFO

$10.9 \mathrm{mg}$ dissolved in 155 uL D2O

$25 \mathrm{C}$

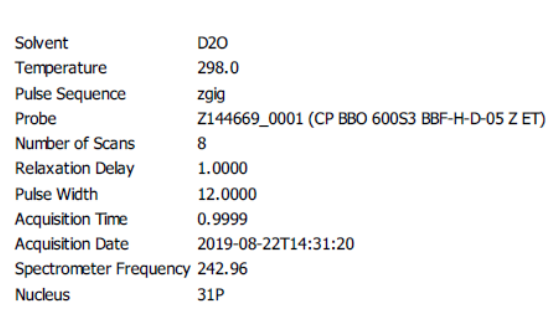

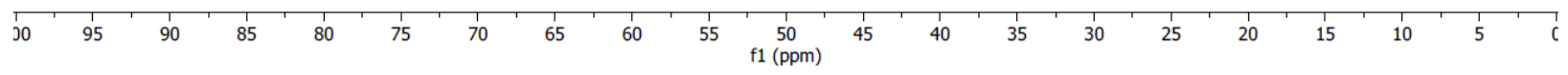

${ }^{31} \mathrm{P}\left\{{ }^{1} \mathrm{H}\right\}$ spectrum $\left(243 \mathrm{MHz}, \mathrm{D}_{2} \mathrm{O}\right)$ of $\mathbf{2}$ collected at $298 \mathrm{~K}$ on a Bruker AVANCE II spectrometer equipped with a liquid-helium cooled BBFO cryoprobe. 


\section{Characterization of 3 by comparison with propylphosphonic acid}

The species related to peak $\mathbf{3}$ was identified as follows:

1) $6.25 \mathrm{mg}(0.0272 \mathrm{mmol})$ of $\mathbf{2} \cdot 2 \mathrm{Na}^{+}$was dissolved in $0.6 \mathrm{ml}$ of water at $\mathrm{pH}$ of 0.3 . This acidic solution of 2 was transferred to a $5 \mathrm{~mm}$ NMR tube and was left at $80^{\circ} \mathrm{C}$ until full conversion to $3 .{ }^{31} \mathrm{P}$ NMR collected for this final solution at room temperature $\left(25^{\circ} \mathrm{C}\right)$ showed only the peak at $32.85 \mathrm{ppm}$. The spectra is shown below.

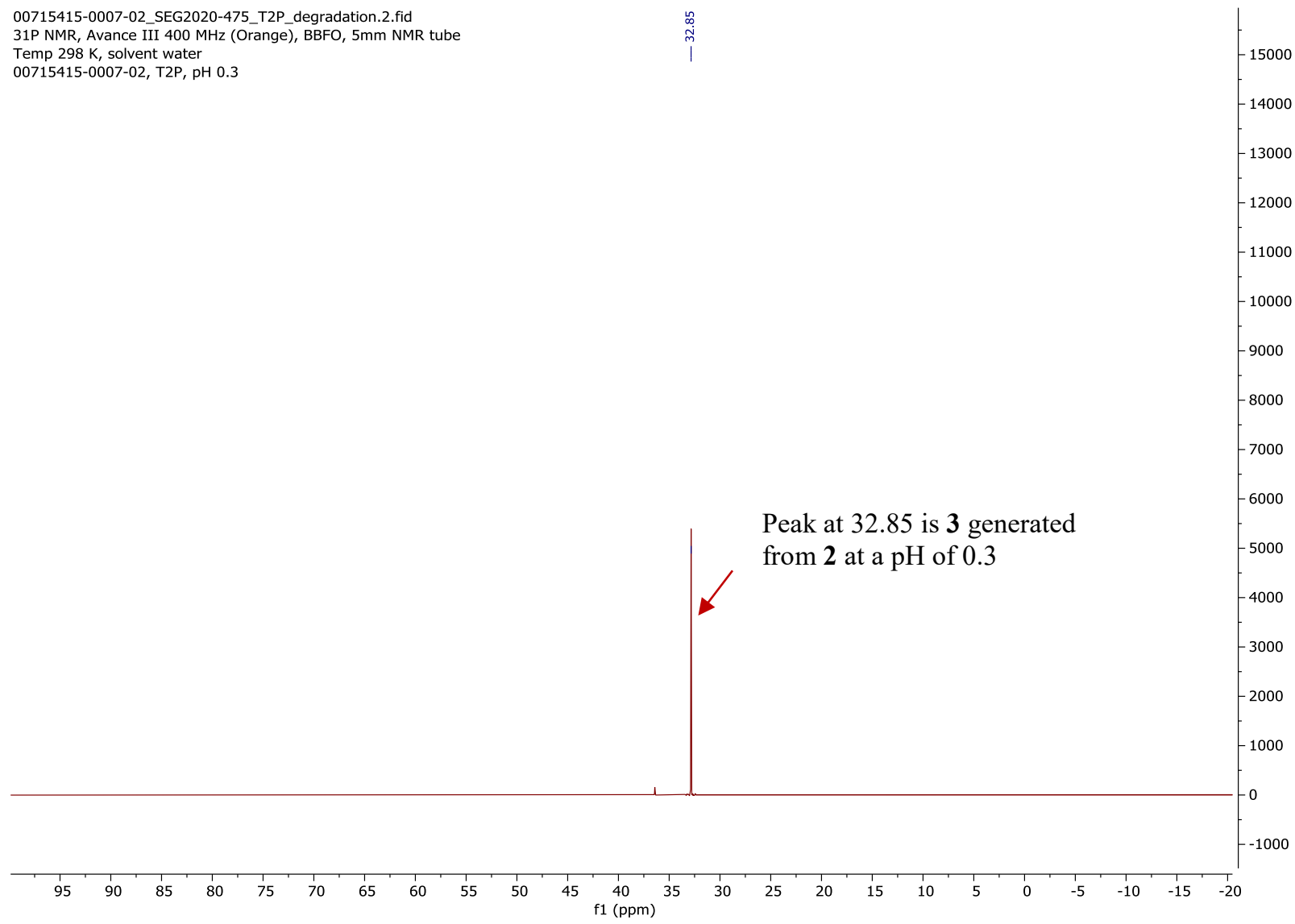

2) To this acidic solution of $\mathbf{3}$ in the $5 \mathrm{~mm}$ NMR tube, a co-axial tube insert containing an aqueous $0.046 \mathrm{M}$ solution of propylphosphonic acid was inserted. Note that the co-axial tube insert contained commercially available propylphosphonic acid with no additional acid or base in the solution and this can be used to reference the spectra. ${ }^{31} \mathrm{P}$ NMR was re-collected for the solution of 3 in the $5 \mathrm{~mm}$ NMR tube with the co-axial insert containing the propylphosphonic acid. 


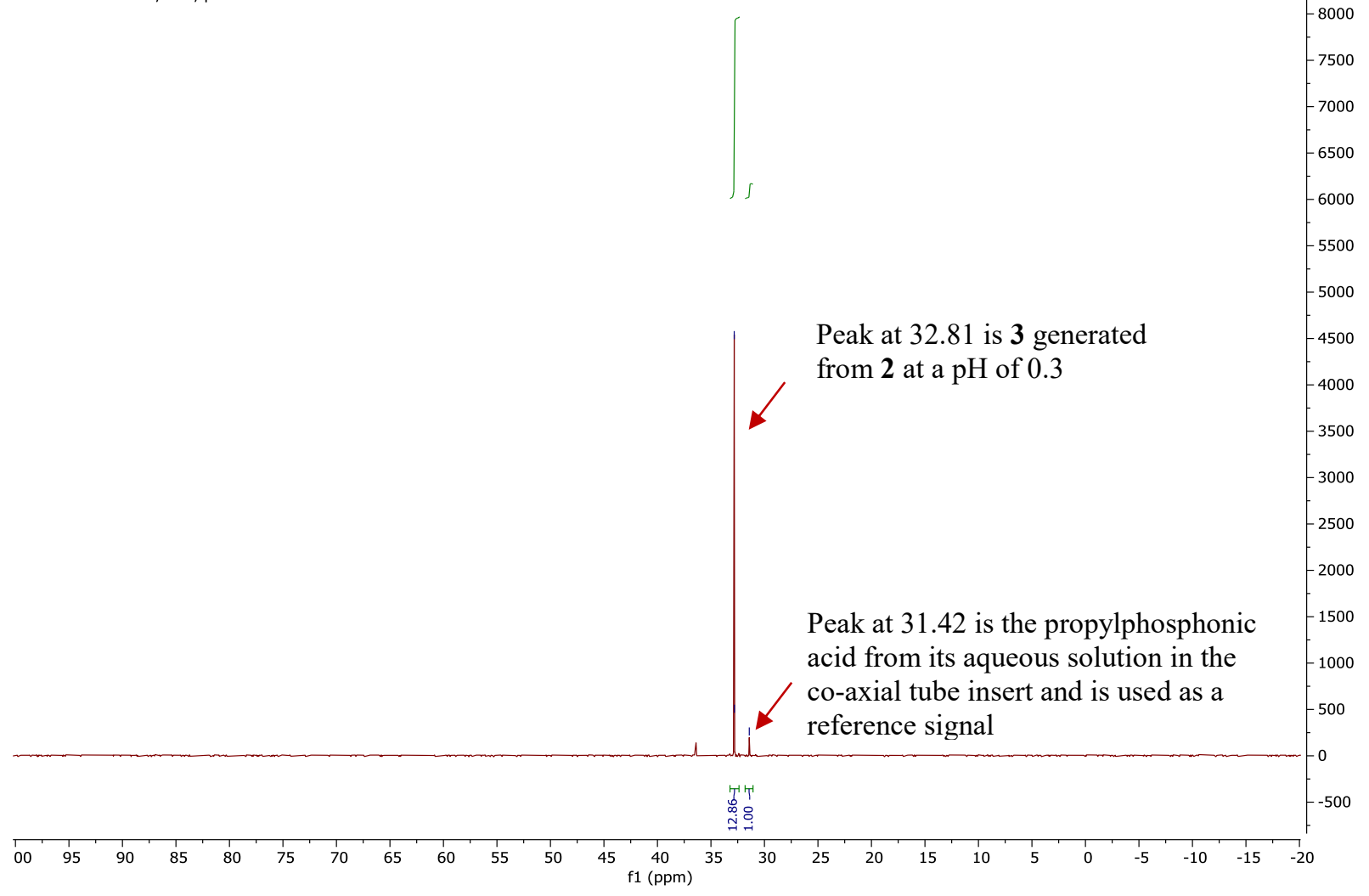

3) To the acidic solution of $\mathbf{3}$, approximately $3.5 \mathrm{mg}(0.0274 \mathrm{mmol})$ of the commercially available propylphosphonic acid is then directly added and the ${ }^{31} \mathrm{P}$ NMR was retaken as shown below. This allowed for comparison of the signal for $\mathbf{3}$ and propylphosphonic acid under equivalent $\mathrm{pH}$ condition. 
00715415-0007-04_SEG2020-475_T2P_degradation.2.fid

31P NMR, Avance III $400 \mathrm{MHz}$ (Orange), BBFO, $5 \mathrm{~mm}$ NMR tube

Temp $298 \mathrm{~K}$, solvent water, propylphosphonic acid in co-axial tube

00715415-0007-04, T2P + propylphosphonic acid spiked, pH 0.3

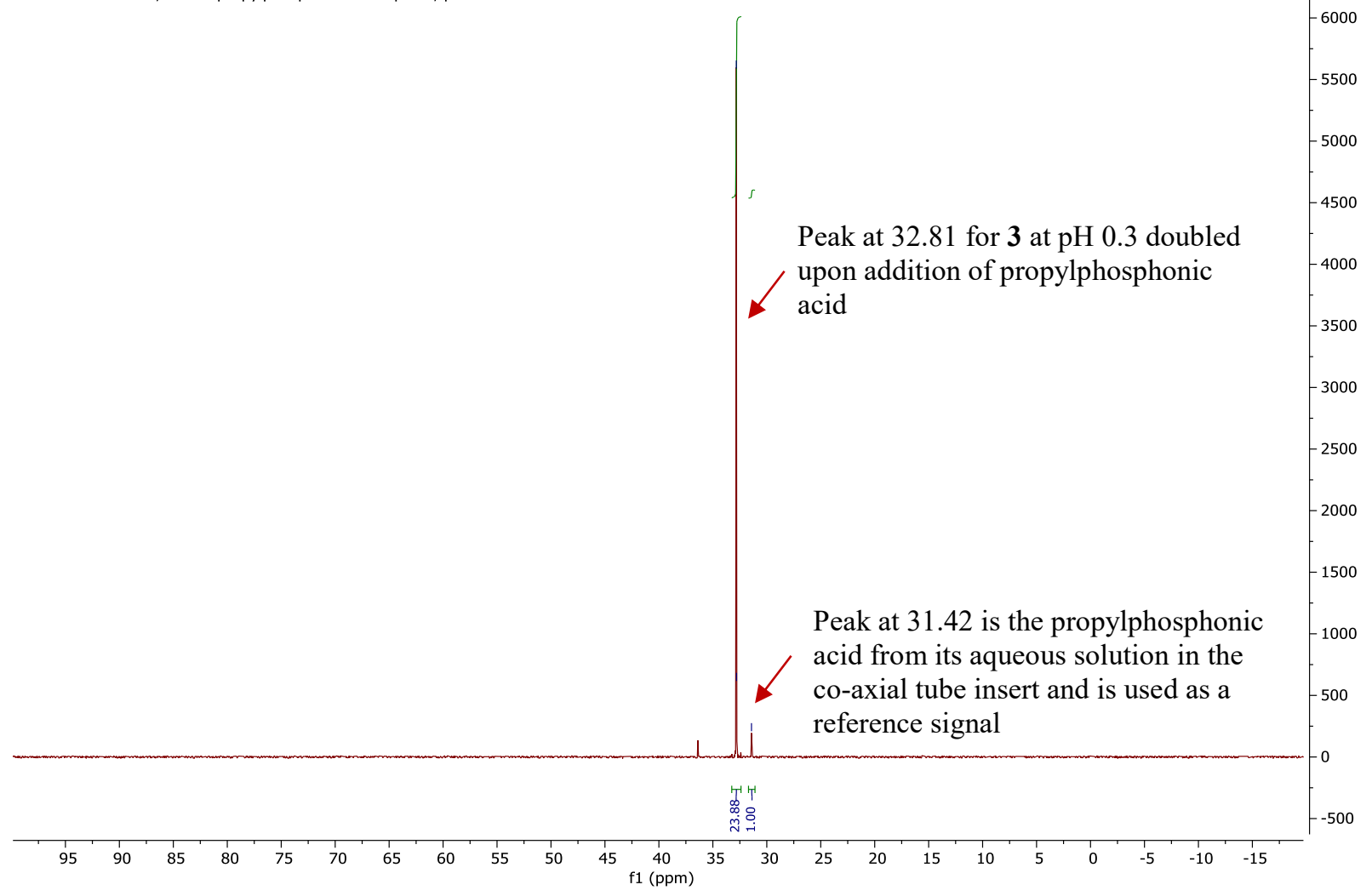

The result of this study showed that addition of this propylphosphonic acid in the acidic solution containing 3 did not change the chemical shift of the existing signal or generate any new signal (when referenced to the signal from co-axial tube). Furthermore, this addition of propylphosphonic acid increased the area of the signal for 3 (this can be found from the integration value of the signal for 3 relative to the reference peak). This provided conclusive evidence that $\mathbf{3}$ is propylphosphonic acid. 


\section{Effect of crown ether on 2}

To explore the effect of crown ether on the stability of $2 \cdot 2 \mathrm{Na}^{+},{ }^{31} \mathrm{P}$ NMR studies were conducted on samples containing 2 and varying equivalence of 18 -crown- 6 ether, as well as, $\mathrm{pH}$. The prepared samples contained $6.15 \mathrm{mg}(0.027 \mathrm{mmol})$ of 2 and 18 -crown-6 $(0,7.1$ or $14.2 \mathrm{mg}$ which corresponds to 0,1 or 2 equivalence) in $0.6 \mathrm{ml}$ of water whose $\mathrm{pH}$ was adjusted to either 11.6, 5.0 or 1.0 depending on the $\mathrm{pH}$ regimes being studied. Note that while the low $\mathrm{pH}(\mathrm{pH} 1.0)$ was obtained by addition of concentrated hydrochloric acid, the high $\mathrm{pH}(\mathrm{pH} 11.6)$ was obtained by addition of ammonium hydroxide. Alkali metal oxide bases were avoided for this experiment to prevent its interaction with the crown ether. Each of the samples were then added to a $5 \mathrm{~mm} \mathrm{NMR}$ tube. A co-axial tube insert containing an aqueous $0.046 \mathrm{M}$ solution of propylphosphonic acid was inserted to the $5 \mathrm{~mm}$ NMR tube containing the sample before collecting any ${ }^{31} \mathrm{P}$ NMR. This coaxial tube insert contained only commercially available propylphosphonic acid and did not contain any additional acids or bases. The propylphosphonic acid signal in this co-axial insert, being isolated from the sample solution, should remain constant and thus was used to reference the entire series of spectra. Furthermore, it doubled as a control sample for the monitoring the possible formation of any of the monomeric propylphosphonic acid (3) from $\mathbf{2}$ in the sample solution.

${ }^{31} \mathrm{P}$ NMR spectra collected for each sample is shown below.

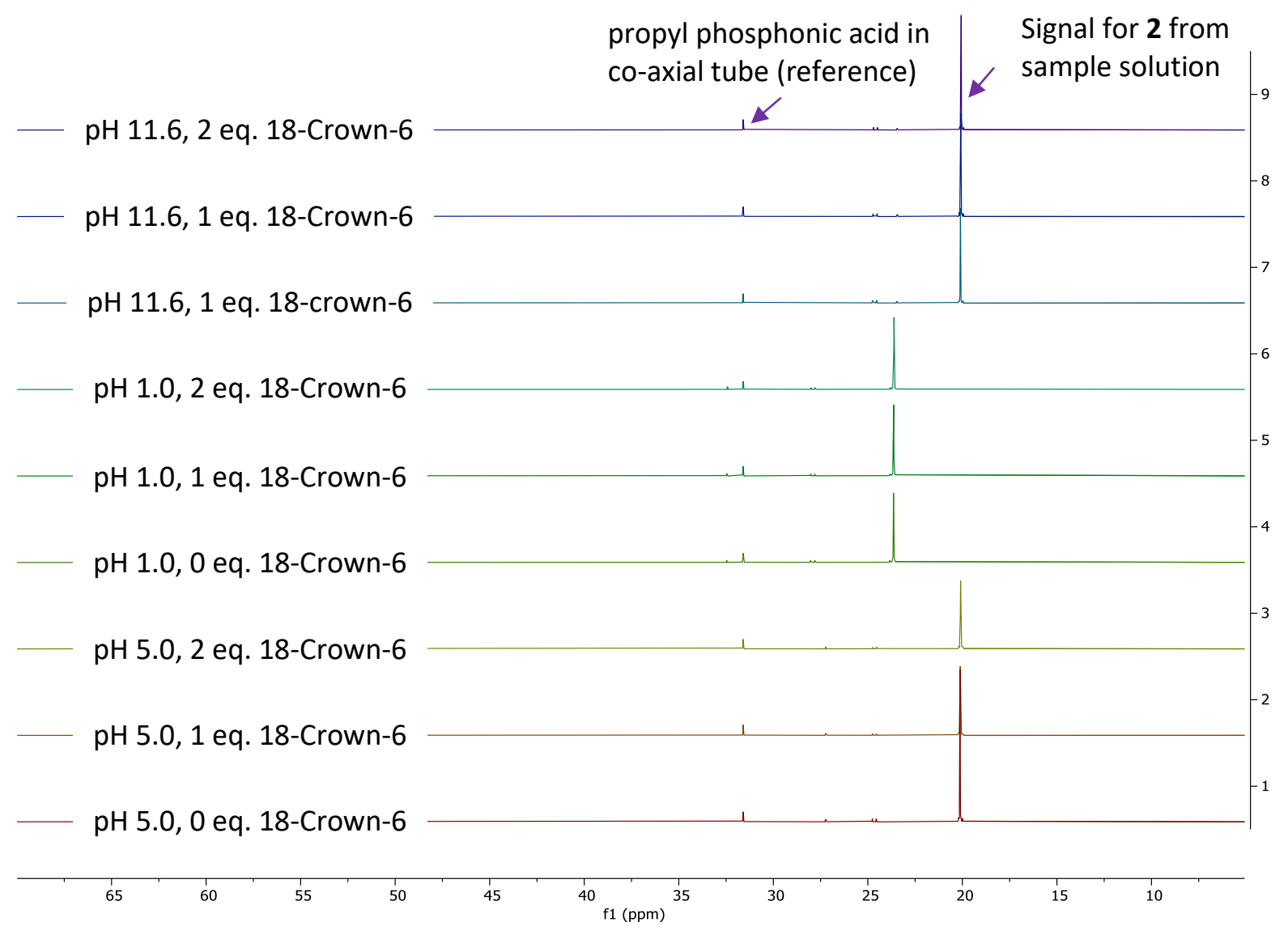


The result of the above study summarized as follows:

1) There is a noticeable and consistent downfield shift of the signal of $\mathbf{2}$ at low $\mathrm{pH}$ by about $3.5 \mathrm{ppm}$. However, downfield shifted signal does not correspond the $\mathbf{3}$, as verified by the use of commercially available propylphosphonic acid as the reference (in the co-axial tube insert). This is also supported by the previous study where the signal of $\mathbf{3}$ was investigated and compared with propylphosphonic acid at low $\mathrm{pH}$. This downfield shifted signal for $\mathbf{2}$ likely corresponds to its protonated form at this low $\mathrm{pH}$.

2) 18-crown-6 did not have any noticeable impact on the signal of $\mathbf{2}$ at any of the $\mathrm{pH}$ regimes studied. This provides further evidence in favor of lack of additional stability by sodium coordination of 2 . 


\section{Variable temperature NMR study}

To explore the effect of temperature on the ${ }^{31} \mathrm{P}$ NMR of $\mathbf{2}$, the following study was conducted. Samples containing $6.15 \mathrm{mg}(0.027 \mathrm{mmol})$ of $2 \cdot 2 \mathrm{Na}^{+}$in a $0.6 \mathrm{ml}$ of $25: 75$ acetonitrile-water mixture were prepared whose were adjusted to 0.4 (acidic), 5.1 (no additional acid or base) or 13.5 (basic). The acidic ( $\mathrm{pH} 0.4$ ) solution's $\mathrm{pH}$ was adjusted by adding concentration hydrochloric acid, while the basic solution ( $\mathrm{pH}$ 13.5) prepared with a solution of $1 \mathrm{~N}$ aqueous sodium hydroxide. A co-axial tube insert containing a $0.046 \mathrm{M}$ solution of propylphosphonic acid in 25:75 acetonitrilewater mixture was inserted to the $5 \mathrm{~mm}$ NMR tube containing the sample before collecting ${ }^{31} \mathrm{P}$ NMR. This co-axial tube insert contained only commercially available propylphosphonic acid and did not contain any additional acids or bases. Similar to prior experiments, the propylphosphonic acid signal in this co-axial insert was used to align and reference the spectra. The temperature range studied were $-6{ }^{\circ} \mathrm{C}$ to $25{ }^{\circ} \mathrm{C}$ (see the spectra below). It is important to note that a lower temperature range could not be explored as $25: 75$ acetonitrile-water mixture freezes near $-10{ }^{\circ} \mathrm{C}$ (Zarzycki P.K. et al. Analytical Sciences 2006, 22, 453-456), while increasing the acetonitrile content can lead to phase separation at low temperature.

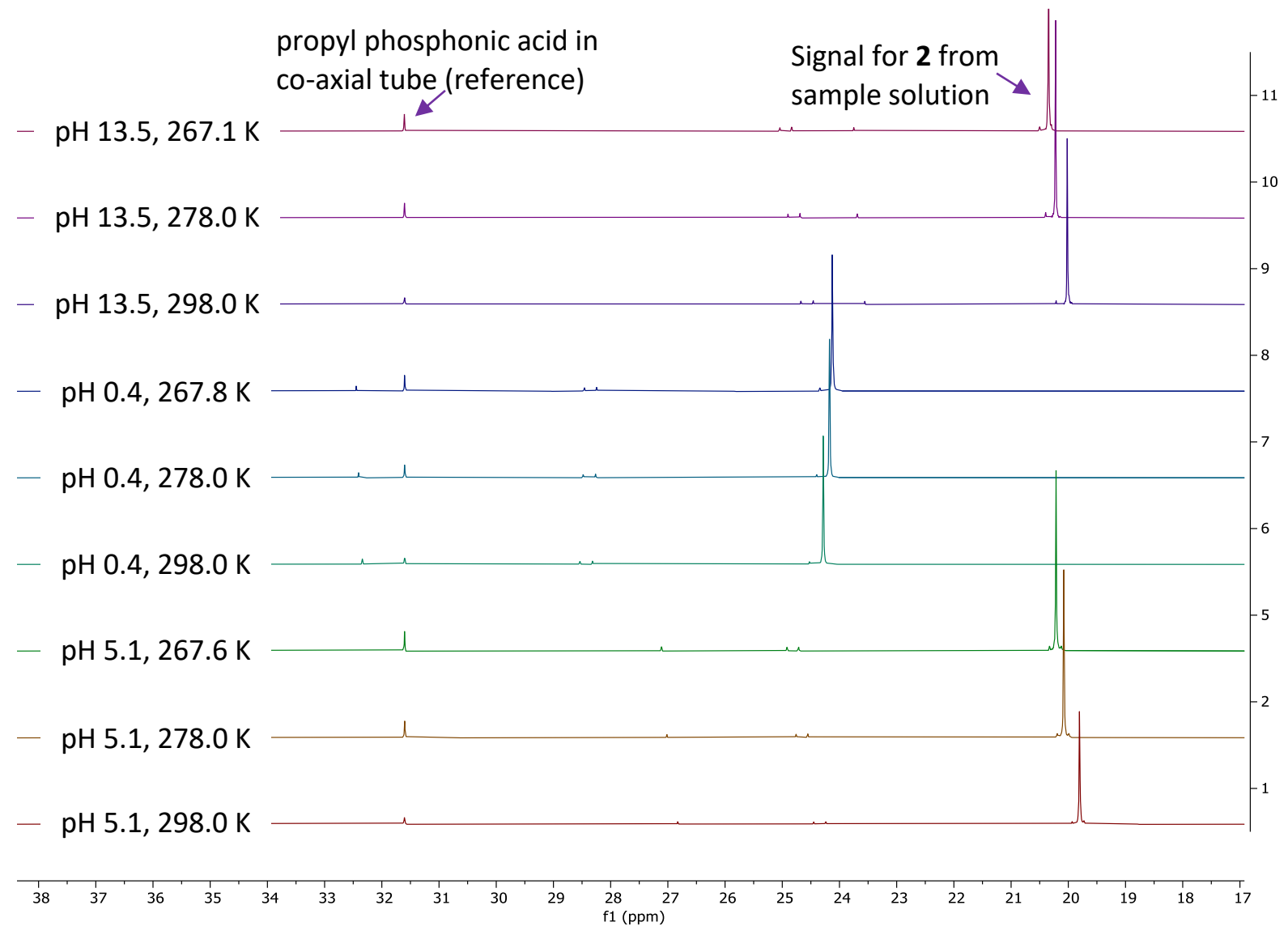

The result of this study has been summarized below: 
1) Signal of $\mathbf{2}$ exhibited a similar downfield shift as discussed in the previous study with 18crown-6, at low $\mathrm{pH}$.

2) While change in temperature did have a small effect on the chemical shifts of the signals corresponding to $\mathbf{2}$, there were no noticeable broadening or splitting of peaks that would be expected from a kinetic deceleration of any underlying dynamic processes. 


\section{Computational analysis of $2 \cdot 2 \mathrm{Na}^{+}$}

Computational method:

Geometry optimization was performed at DFT/M062X/6-31g(d,p)/water(SMD) level of theory using Gaussian16 software ${ }^{i}$. Donor-acceptor interaction energy was obtained based second order perturbation theory using NBO6. ${ }^{\text {ii }}$

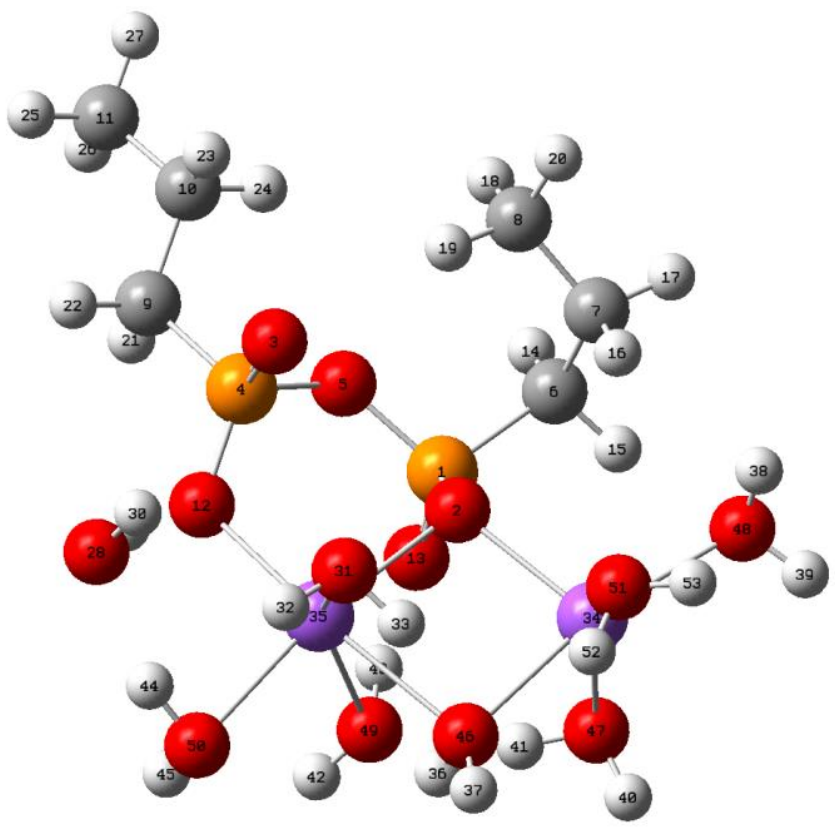

Purple: Na; Red, O; Orange: P; Dark grey: C; Light grey: H.

Coordinates:

$\begin{array}{rrrrrr}1 & 15 & 0 & -0.095190 & 1.219224 & -0.905733 \\ 2 & 8 & 0 & 0.758294 & 0.509395 & 0.139255 \\ 3 & 8 & 0 & -1.959348 & -0.522405 & 1.573766 \\ 4 & 15 & 0 & -2.160347 & -0.570856 & 0.078433 \\ 5 & 8 & 0 & -1.675593 & 0.861582 & -0.601748 \\ 6 & 6 & 0 & -0.059882 & 3.007569 & -0.670375 \\ 7 & 6 & 0 & -0.169085 & 3.481361 & 0.783538 \\ 8 & 6 & 0 & -1.520516 & 3.201579 & 1.438394 \\ 9 & 6 & 0 & -3.908976 & -0.533608 & -0.363868 \\ 10 & 6 & 0 & -4.661995 & 0.643385 & 0.260382 \\ 11 & 6 & 0 & -6.143059 & 0.623895 & -0.102076 \\ 12 & 8 & 0 & -1.433549 & -1.689438 & -0.675524 \\ 13 & 8 & 0 & 0.192689 & 0.861680 & -2.357425 \\ 14 & 1 & 0 & -0.859373 & 3.438651 & -1.283905 \\ 15 & 1 & 0 & 0.891075 & 3.337848 & -1.103374 \\ 16 & 1 & 0 & 0.629034 & 3.017798 & 1.374235\end{array}$




\begin{tabular}{|c|c|c|c|c|c|}
\hline 17 & 1 & 0 & 0.021860 & 4.559540 & 0.794199 \\
\hline 18 & 1 & 0 & -2.340371 & 3.571813 & 0.813175 \\
\hline 19 & 1 & 0 & -1.680660 & 2.132245 & 1.601293 \\
\hline 20 & 1 & 0 & -1.585548 & 3.702023 & 2.408493 \\
\hline 21 & 1 & 0 & -3.981208 & -0.509786 & -1.456793 \\
\hline 22 & 1 & 0 & -4.337676 & -1.485787 & -0.028721 \\
\hline 23 & 1 & 0 & -4.542021 & 0.609131 & 1.348863 \\
\hline 24 & 1 & 0 & -4.207711 & 1.581946 & -0.077483 \\
\hline 25 & 1 & 0 & -6.617294 & -0.297764 & 0.249465 \\
\hline 26 & 1 & 0 & -6.279002 & 0.676926 & -1.186794 \\
\hline 27 & 1 & 0 & -6.672704 & 1.468732 & 0.346414 \\
\hline 28 & 8 & 0 & -1.236094 & -3.941757 & 0.817209 \\
\hline 29 & 1 & 0 & -1.449437 & -3.147890 & 0.273410 \\
\hline 30 & 1 & 0 & -1.074833 & -3.583298 & 1.700683 \\
\hline 31 & 8 & 0 & 1.209826 & -2.203418 & 2.153756 \\
\hline 32 & 1 & 0 & 1.187178 & -3.169296 & 2.203071 \\
\hline 33 & 1 & 0 & 2.130883 & -1.996077 & 1.932339 \\
\hline 34 & 11 & 0 & 2.971896 & 0.822324 & 0.322085 \\
\hline 35 & 11 & 0 & 0.799610 & -1.783510 & -0.113364 \\
\hline 36 & 1 & 0 & 3.151549 & -1.648642 & -0.841550 \\
\hline 37 & 1 & 0 & 3.980858 & -2.041996 & 0.406295 \\
\hline 38 & 1 & 0 & 2.961795 & 3.365429 & 1.429714 \\
\hline 39 & 1 & 0 & 4.099584 & 3.379520 & 0.408931 \\
\hline 40 & 1 & 0 & 4.444941 & 0.663968 & -2.010384 \\
\hline 41 & 1 & 0 & 3.024808 & 0.129042 & -2.235813 \\
\hline 42 & 1 & 0 & 1.628908 & -1.902546 & -2.961045 \\
\hline 43 & 1 & 0 & 1.096640 & -0.534152 & -2.388218 \\
\hline 44 & 1 & 0 & 0.346451 & -4.233470 & 0.006946 \\
\hline 45 & 1 & 0 & 0.980599 & -4.191879 & -1.398735 \\
\hline 46 & 8 & 0 & 3.250168 & -1.482832 & 0.111203 \\
\hline 47 & 8 & 0 & 3.514915 & 0.914584 & -1.930782 \\
\hline 48 & 8 & 0 & 3.183726 & 3.094173 & 0.528890 \\
\hline 49 & 8 & 0 & 1.742504 & -1.278073 & -2.233115 \\
\hline 50 & 8 & 0 & 1.191334 & -4.066037 & -0.463844 \\
\hline 51 & 8 & 0 & 3.516757 & 0.319076 & 2.485943 \\
\hline 52 & 1 & 0 & 3.990383 & -0.521525 & 2.422469 \\
\hline 53 & 1 & 0 & 4.143812 & 0.919689 & 2.909750 \\
\hline
\end{tabular}

Zero-point correction=

Thermal correction to Energy= Thermal correction to Enthalpy= Thermal correction to Gibbs Free Energy= Sum of electronic and zero-point Energies= Sum of electronic and thermal Energies= Sum of electronic and thermal Enthalpies=

\author{
0.414522 (Hartree/Particle) \\ 0.457503 \\ 0.458447 \\ 0.338556 \\ $-2231.427625$ \\ $-2231.384644$ \\ $-2231.383700$
}


NBO6 Donor-acceptor interaction energy:

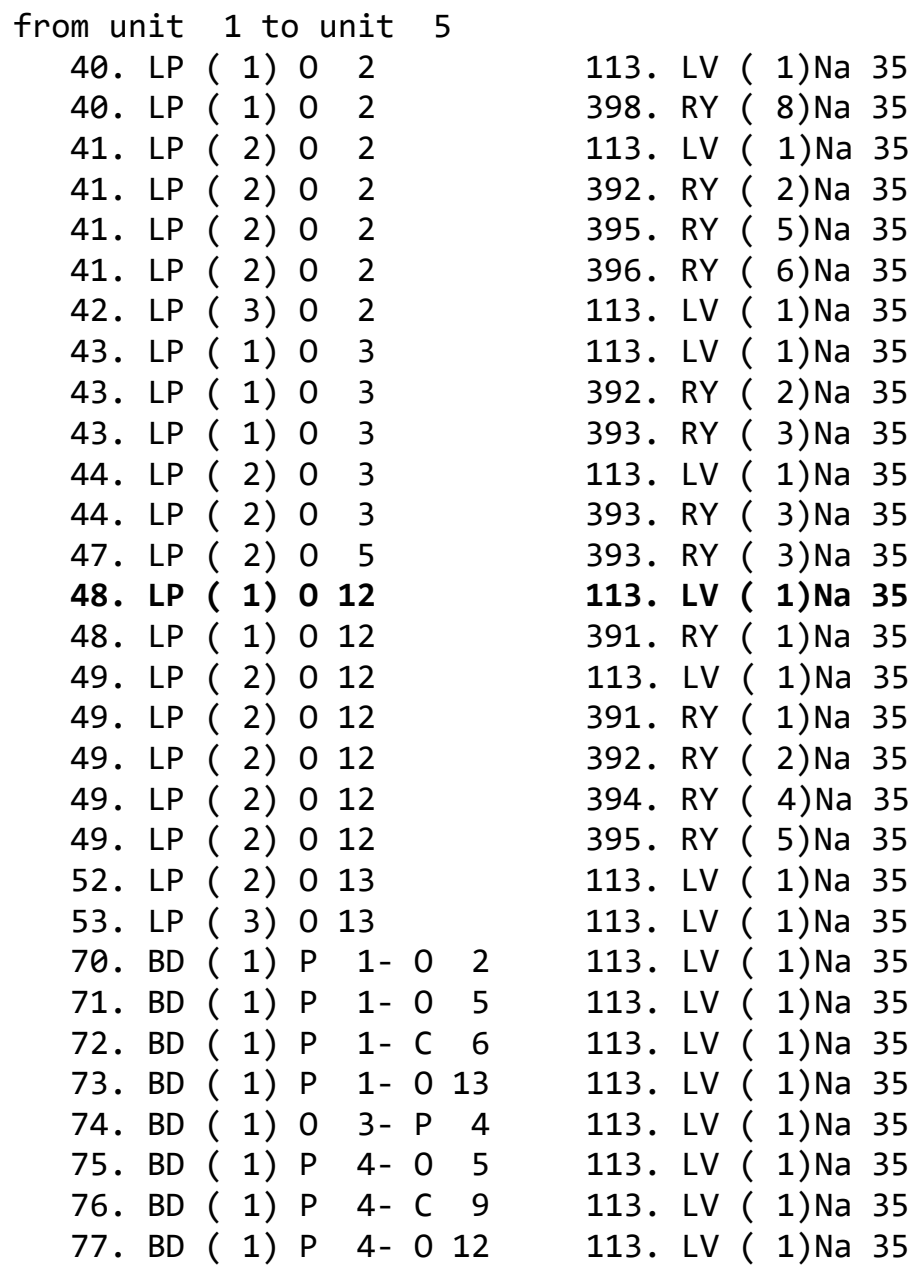

from unit 10 to unit 5

66. LP ( 1) 050

66. LP ( 1) 050

66. LP ( 1) 050

66. LP ( 1) 050

67. LP ( 2) 050

67. LP ( 2) 050

67. LP ( 2) 050

67. LP ( 2) 050

108. BD ( 1$)$ H 44- 050

108. BD ( 1) H 44- 050

108. BD ( 1) H 44- 050

108. BD ( 1) H 44- 050

108. BD ( 1) H 44- 050

109. BD ( 1) H 45- 050

109. BD ( 1$) \mathrm{H} 45-050$

109. BD ( 1 ) H $45-050$
113. LV ( 1) Na 35

391. RY ( 1) Na 35

392. RY ( 2) Na 35

393. RY ( 3$) \mathrm{Na} 35$

113. LV ( 1) Na 35

391. RY ( 1) Na 35

394. RY ( 4) Na 35

395. RY ( 5) Na 35

113. LV ( 1) Na 35

391. RY ( 1) Na 35

396. RY ( 6) Na 35

397. RY ( 7) Na 35

113. LV ( 1) Na 35

394. RY ( 4) Na 35

395. RY ( 5) Na 35
395. RY ( 5) Na 35

$\begin{array}{lll}8.49 & 0.88 & 0.077 \\ 0.07 & 1.55 & 0.009 \\ 1.57 & 0.55 & 0.026 \\ 0.12 & 0.67 & 0.008 \\ 0.15 & 1.06 & 0.011 \\ 0.08 & 0.76 & 0.007 \\ 0.13 & 0.55 & 0.008 \\ 0.42 & 0.86 & 0.017 \\ 0.08 & 0.99 & 0.008 \\ 0.12 & 0.96 & 0.009 \\ 0.59 & 0.52 & 0.016 \\ 0.28 & 0.62 & 0.012 \\ 0.07 & 0.71 & 0.006 \\ 7.86 & 0.87 & 0.074 \\ 0.08 & 1.13 & 0.008 \\ 2.72 & 0.55 & 0.035 \\ 0.28 & 0.81 & 0.013 \\ 0.07 & 0.68 & 0.006 \\ 0.06 & 0.88 & 0.006 \\ 0.23 & 1.06 & 0.014 \\ 0.09 & 0.54 & 0.006 \\ 0.06 & 0.55 & 0.005 \\ 1.76 & 1.07 & 0.039 \\ 0.12 & 1.02 & 0.010 \\ 0.21 & 0.77 & 0.011 \\ 0.19 & 1.06 & 0.013 \\ 0.18 & 1.06 & 0.012 \\ 0.12 & 1.01 & 0.010 \\ 0.38 & 0.76 & 0.015 \\ 1.50 & 1.05 & 0.035\end{array}$

$\begin{array}{rrr}0.74 & 0.74 & 0.021 \\ 0.05 & 0.99 & 0.006 \\ 0.78 & 0.86 & 0.023 \\ 0.25 & 0.84 & 0.013 \\ 10.04 & 0.68 & 0.073 \\ 0.12 & 0.93 & 0.009 \\ 0.12 & 1.01 & 0.010 \\ 0.18 & 1.19 & 0.013 \\ 1.87 & 0.99 & 0.038 \\ 0.08 & 1.24 & 0.009 \\ 0.10 & 1.50 & 0.011 \\ 0.06 & 1.20 & 0.008 \\ 0.06 & 1.27 & 0.008 \\ 1.70 & 0.96 & 0.036 \\ 0.13 & 1.30 & 0.012 \\ 0.12 & 1.48 & 0.012\end{array}$




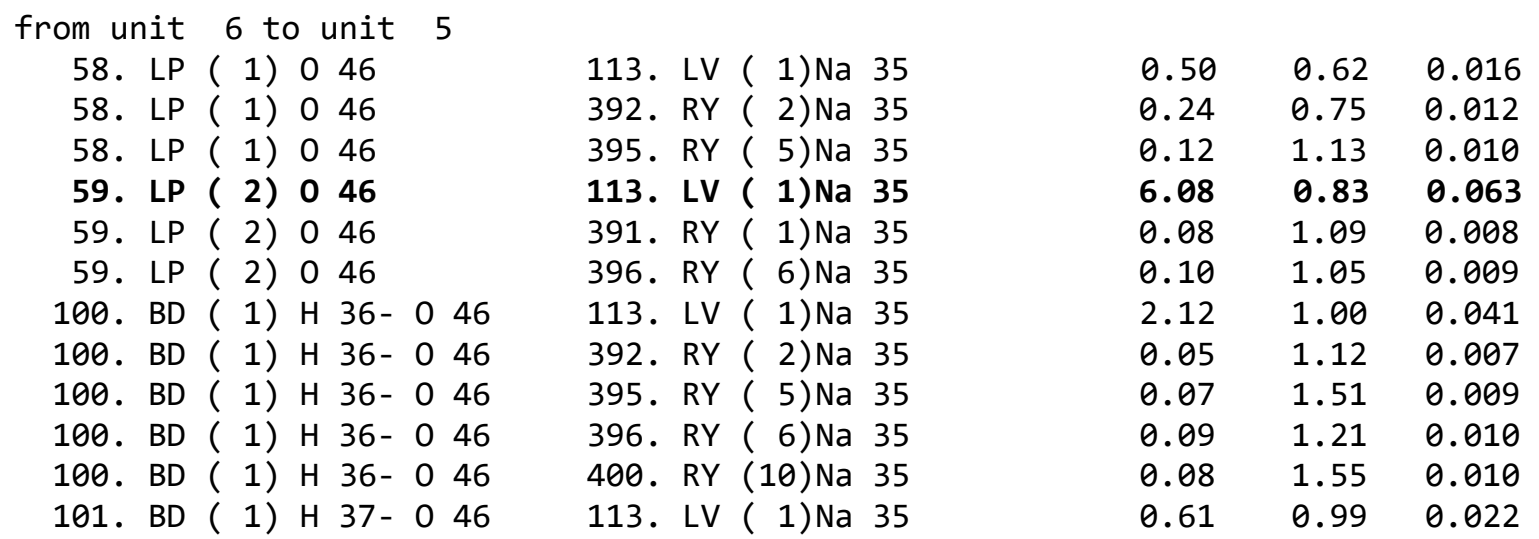




\section{Characterization of 9 and 10 (from reaction mixture, as shown below)}

MS Characterization of 6, 9 and 10

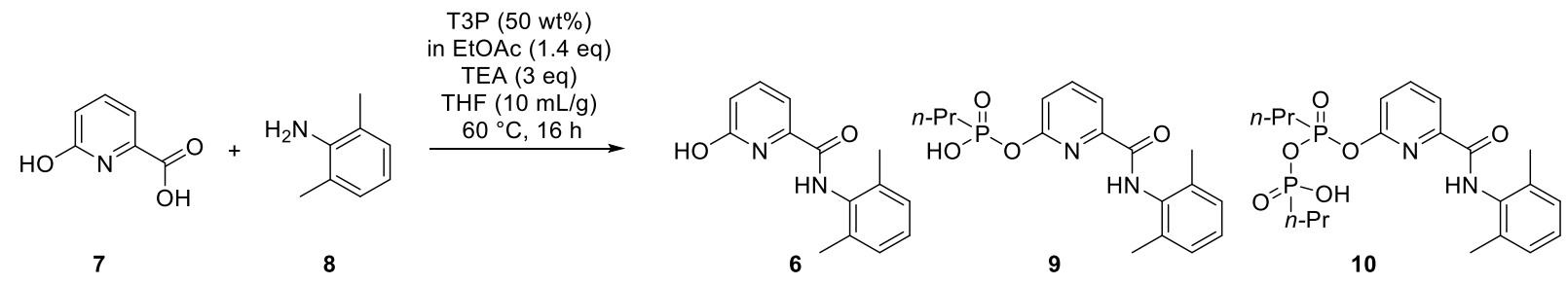

LC/MS characterization of a reaction mixture detected ligand $\mathbf{6}$ and compound $\mathbf{9}$ and $\mathbf{1 0}$ using the following parameters.

Thermo Fusion Lumos Mass Spectrometer, ES+ conditions:

Spray Voltage: 3500V

Sheath gas:50

Aux gas: 10

Sweep gas: 1

Ion Transfer Tube temp: 325C

RF Lens:50

Aux gas heater: 350C

Scan Range:150-1500 Daltons full scan

Resolving Power: $\sim 60000$

Thermo Vanquish UPLC parameters

Column: HSS T3 $2.1 \times 50 \mathrm{~mm}$

mobile phase A: aqueous $0.05 \%$ TFA

mobile phase B: acetonitrile

flow rate $0.50 \mathrm{~mL} / \mathrm{min}$

$\mathrm{UV}: 254 \mathrm{~nm}$

$45 \mathrm{C}$ column temp

Gradient: $5 \%$ B to $95 \%$ B at 3 minutes

Compound 6: Calculated for $\mathrm{C}_{14} \mathrm{H}_{14} \mathrm{~N}_{2} \mathrm{O}_{2}$ : 242.1055, Observed: 243.1130

Compound 9: Calculated for $\mathrm{C}_{17} \mathrm{H}_{21} \mathrm{~N}_{2} \mathrm{O}_{4} \mathrm{P}: 348.1239$, Observed: 349.1316

Compound 10: Calculated for $\mathrm{C}_{20} \mathrm{H}_{28} \mathrm{~N}_{2} \mathrm{O}_{6} \mathrm{P}_{2}$ : 454.1423, Observed 455.1499 


\section{NMR Characterization of $1,6,9$ and 10}<smiles>CCCP(=O)([O-])OP(=O)([O-])OP(=O)([O-])P(=O)([O-])OCC</smiles>

1<smiles>Cc1cccc(C)c1NC(=O)c1cccc(O)n1</smiles>

6

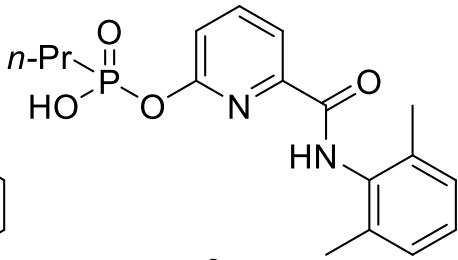

9

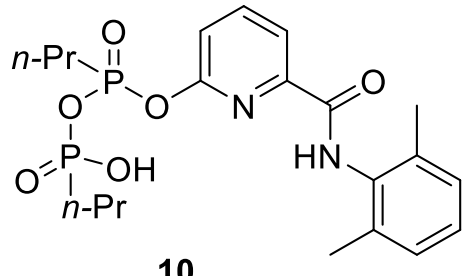

10

Compound 1: ${ }^{1} \mathrm{H}$ NMR $(600 \mathrm{MHz}): \delta_{\mathrm{H}} 2.29\left(2 \mathrm{H}, \mathrm{m},{ }^{2} J_{\mathrm{HP}}=17.6 \mathrm{~Hz}\right), 1.99(2 \mathrm{H}, \mathrm{m}), 1.91(4 \mathrm{H}, \mathrm{m})$, $1.89\left(4 \mathrm{H}, \mathrm{m},{ }^{2} J_{\mathrm{HP}}=15.2 \mathrm{~Hz}\right), 1.27(9 \mathrm{H}, \mathrm{m}) .{ }^{13} \mathrm{C}\left\{{ }^{1} \mathrm{H}\right\} \mathrm{NMR}(150 \mathrm{MHz}): \delta_{\mathrm{C}} 32.0\left(\mathrm{~d},{ }^{1} J_{\mathrm{CP}}=139.8\right.$ $\mathrm{Hz}), 30.3\left(\mathrm{~d},{ }^{1} J_{\mathrm{CP}}=139.7 \mathrm{~Hz}\right), 17.3\left(\mathrm{~d},{ }^{2} J_{\mathrm{CP}}=4.7 \mathrm{~Hz}\right), 16.3\left(\mathrm{~d},{ }^{2} J_{\mathrm{CP}}=5.1 \mathrm{~Hz}\right), 15.2\left(\mathrm{~d},{ }^{3} J_{\mathrm{CP}}=17.5\right.$ $\mathrm{Hz}) .{ }^{31} \mathrm{P}\left\{{ }^{1} \mathrm{H}\right\} \mathrm{NMR}(243 \mathrm{MHz}): \delta_{\mathrm{P}} 16.8\left(\mathrm{~d},{ }^{2} J_{\mathrm{PP}}=28.3 \mathrm{~Hz}\right), 11.0\left(\mathrm{t},{ }^{2} J_{\mathrm{PP}}=28.3 \mathrm{~Hz}\right)$.

Compound 6: ${ }^{1} \mathrm{H}$ NMR $(600 \mathrm{MHz}): \delta_{\mathrm{H}} 11.21(1 \mathrm{H}, \mathrm{s}, \mathrm{NH}), 7.94(1 \mathrm{H}, \mathrm{t}, J=7.7 \mathrm{~Hz}), 7.82-7.89(1 \mathrm{H})$, 7.35-7.41 $(2 \mathrm{H}), 7.32-7.35(1 \mathrm{H}), 7.08-7.12(1 \mathrm{H}), 2.52-2.60(6 \mathrm{H}) .{ }^{13} \mathrm{C}\left\{{ }^{1} \mathrm{H}\right\} \mathrm{NMR}(150 \mathrm{MHz}): \delta_{\mathrm{C}}$ $164.5,162.4,148.0,138.8,136.4,135.7,127.5,125.5-125.8,113.4,112.0,18.0-18.1$.

Compound 9: ${ }^{1} \mathrm{H}$ NMR (600 MHz): $\delta_{\mathrm{H}} 9.99(1 \mathrm{H}, \mathrm{s}, \mathrm{N} \underline{\mathrm{H}}), 8.17-8.27(1 \mathrm{H}), 8.14(1 \mathrm{H}, \mathrm{m}), 7.82-7.91$ $(1 \mathrm{H}), 7.35-7.41(1 \mathrm{H}), 7.32-7.35(2 \mathrm{H}), 2.52-2.60(6 \mathrm{H}), 2.00\left(2 \mathrm{H},{ }^{2} J_{\mathrm{HP}}=14.6 \mathrm{~Hz}\right), 1.93-2.02(2 \mathrm{H})$, $1.27(3 \mathrm{H}, \mathrm{m}) .{ }^{13} \mathrm{C}\left\{{ }^{1} \mathrm{H}\right\} \mathrm{NMR}(150 \mathrm{MHz}): \delta_{\mathrm{C}} 161.6,159.7\left(\mathrm{~d},{ }^{2} J_{\mathrm{CP}}=5.1 \mathrm{~Hz}\right), 148.4,139.8,135.0$, 135.0, 127.1, 126.2, 117.4, 116.1, $30.2\left(\mathrm{~d},{ }^{1} J_{\mathrm{CP}}=139.1 \mathrm{~Hz}\right), 17.9,17.4\left(\mathrm{~d},{ }^{2} J_{\mathrm{CP}}=5.0 \mathrm{~Hz}\right), 14.8(\mathrm{~d}$, $\left.{ }^{3} J_{\mathrm{CP}}=18.9 \mathrm{~Hz}\right) .{ }^{31} \mathrm{P}\left\{{ }^{1} \mathrm{H}\right\} \mathrm{NMR}(243 \mathrm{MHz}): \delta \mathrm{P} 20.3$.

Compound 10: ${ }^{1} \mathrm{H}$ NMR (600 MHz): $\delta_{\mathrm{H}} 11.70(1 \mathrm{H}, \mathrm{s}, \mathrm{N} \underline{\mathrm{H}}), 8.37(1 \mathrm{H}, \mathrm{m}), 8.17-8.27(1 \mathrm{H}), 7.51$ $(1 \mathrm{H}, \mathrm{m}), 7.32-7.39(2 \mathrm{H}), 7.32-7.36(1 \mathrm{H}), 2.60-2.69\left(1 \mathrm{H},{ }^{2} J_{\mathrm{HP}}=18.1 \mathrm{~Hz}\right), 2.48-2.60\left(1 \mathrm{H},{ }^{2} J_{\mathrm{HP}}=\right.$ $18.1 \mathrm{~Hz}), 2.52-2.60(6 \mathrm{H}), 2.04-2.11(2 \mathrm{H}), 1.72-1.83\left(2 \mathrm{H},{ }^{2} J_{\mathrm{HP}}=17.5 \mathrm{~Hz}\right), 1.72-1.83(2 \mathrm{H}), 1.32$ $(3 \mathrm{H}, \mathrm{m}), 1.16(3 \mathrm{H}, \mathrm{m}) .{ }^{13} \mathrm{C}\left\{{ }^{1} \mathrm{H}\right\} \mathrm{NMR}(150 \mathrm{MHz}): \delta_{\mathrm{C}} 162.0,157.3\left(\mathrm{~d},{ }^{2} J_{\mathrm{CP}}=9.1 \mathrm{~Hz}\right), 149.6,141.1$, $136.3,135.7,127.4,125.5-125.8,118.4,115.4,32.0\left(\mathrm{~d},{ }^{1} J_{\mathrm{CP}}=139.3 \mathrm{~Hz}\right), 30.1\left(\mathrm{~d},{ }^{1} J_{\mathrm{CP}}=136.0\right.$ $\mathrm{Hz}), 18.0-18.1,17.2-17.3,15.9\left(\mathrm{~d},{ }^{2} J_{\mathrm{CP}}=5.0 \mathrm{~Hz}\right), 14.7-15.3,14.6-15.0 .{ }^{31} \mathrm{P}\left\{{ }^{1} \mathrm{H}\right\} \mathrm{NMR}(243 \mathrm{MHz})$ : $\delta_{\mathrm{P}} 17.1\left(\mathrm{~d},{ }^{2} J_{\mathrm{PP}}=33.9 \mathrm{~Hz}\right), 15.0\left(\mathrm{~d},{ }^{2} J_{\mathrm{PP}}=33.9 \mathrm{~Hz}\right)$.

Note: NMR data were collected with a crude reaction mixture as described in Figure 5. NMR experiments were performed without a lock nucleus. ${ }^{1} \mathrm{H}$ chemical shift was referenced by setting the $-\mathrm{CH}_{2}$ proton signal of EtOAc to $4.35 \mathrm{ppm} .{ }^{13} \mathrm{C}$ chemical shift was referenced by setting the $\mathrm{CH}_{2}$ carbon signal of EtOAc to $59.4 \mathrm{ppm} .{ }^{31} \mathrm{P}$ chemical shift was referenced by setting the triplet ${ }^{31} \mathrm{P}$ signal of ligand $\mathbf{1}$ to $11.0 \mathrm{ppm}$. For resonances of ligands $\mathbf{6 , 9}$, and $\mathbf{1 0}$ that mutually overlap, the range of chemical shifts is listed and no line shape information is indicated. 
00712555-0155_SEG2020-439-440.1.fid

$\mathrm{H} 1, \mathrm{BBFO} 600 \mathrm{MHz}, \mathrm{Y} \mathrm{Liu}, 12 / 3 / 2020$

713582-377-06 rxn crude, $25 \mathrm{C}$

일
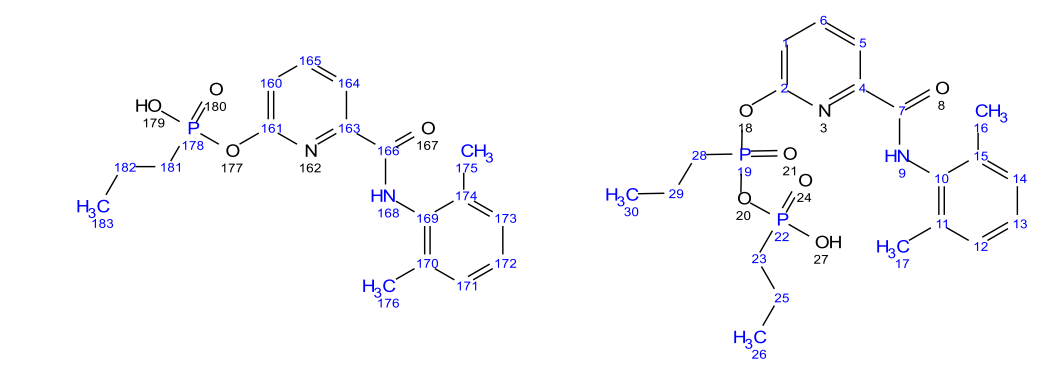

171,173
72

71,73<smiles></smiles>

71,73
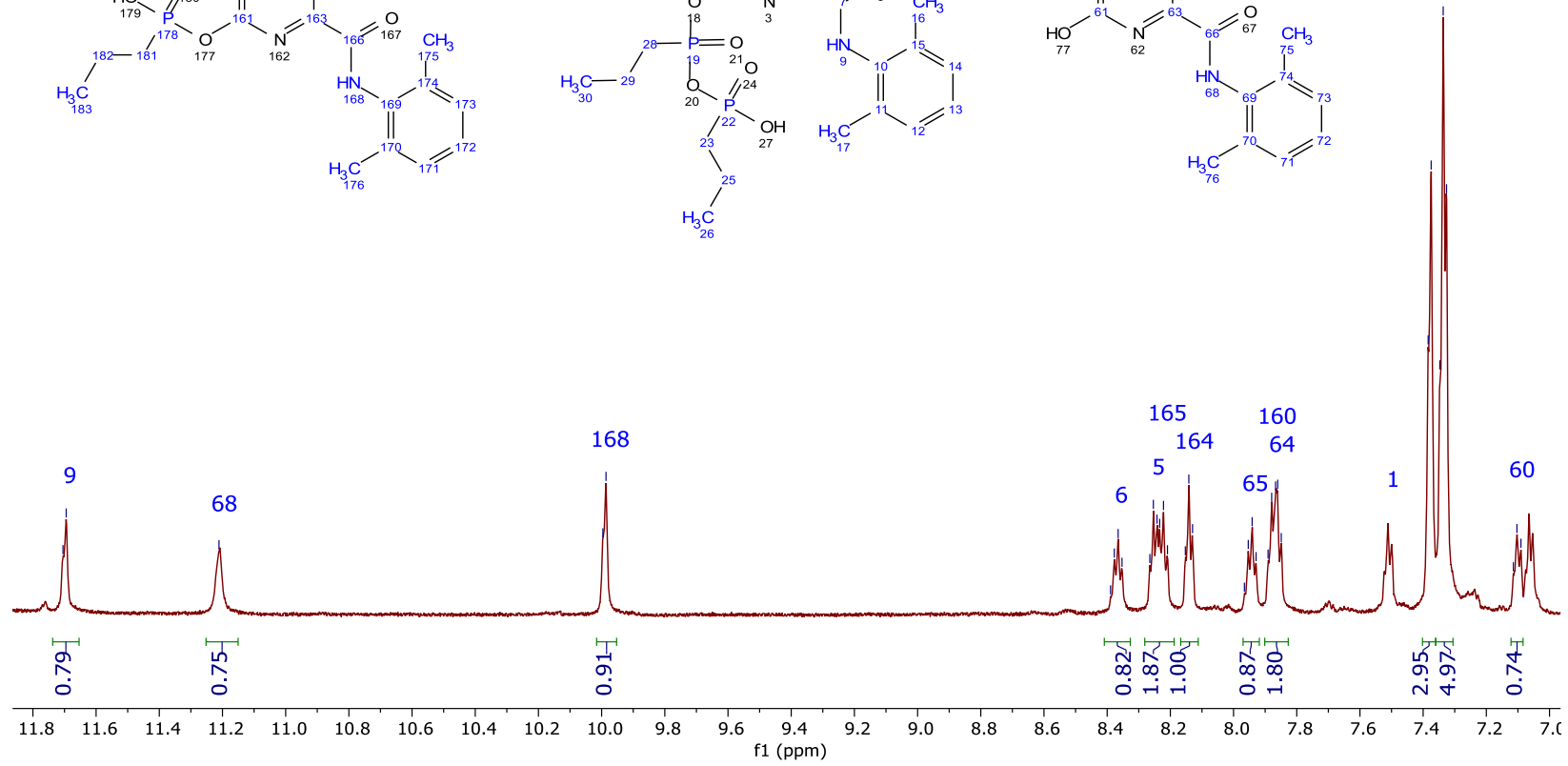

${ }^{1} \mathrm{H}$ spectrum $(600 \mathrm{MHz})$ of crude reaction mixture showing the amide and aromatic protons with assignment annotation. 
00712555-0155_SEG2020-439-440.5.fid

BBFO $600 \mathrm{MHz}, \mathrm{C} 13\{\mathrm{H} 1\}, 12 / 3 / 2020$

713582-377-06 rxn crude, $25 \mathrm{C}$
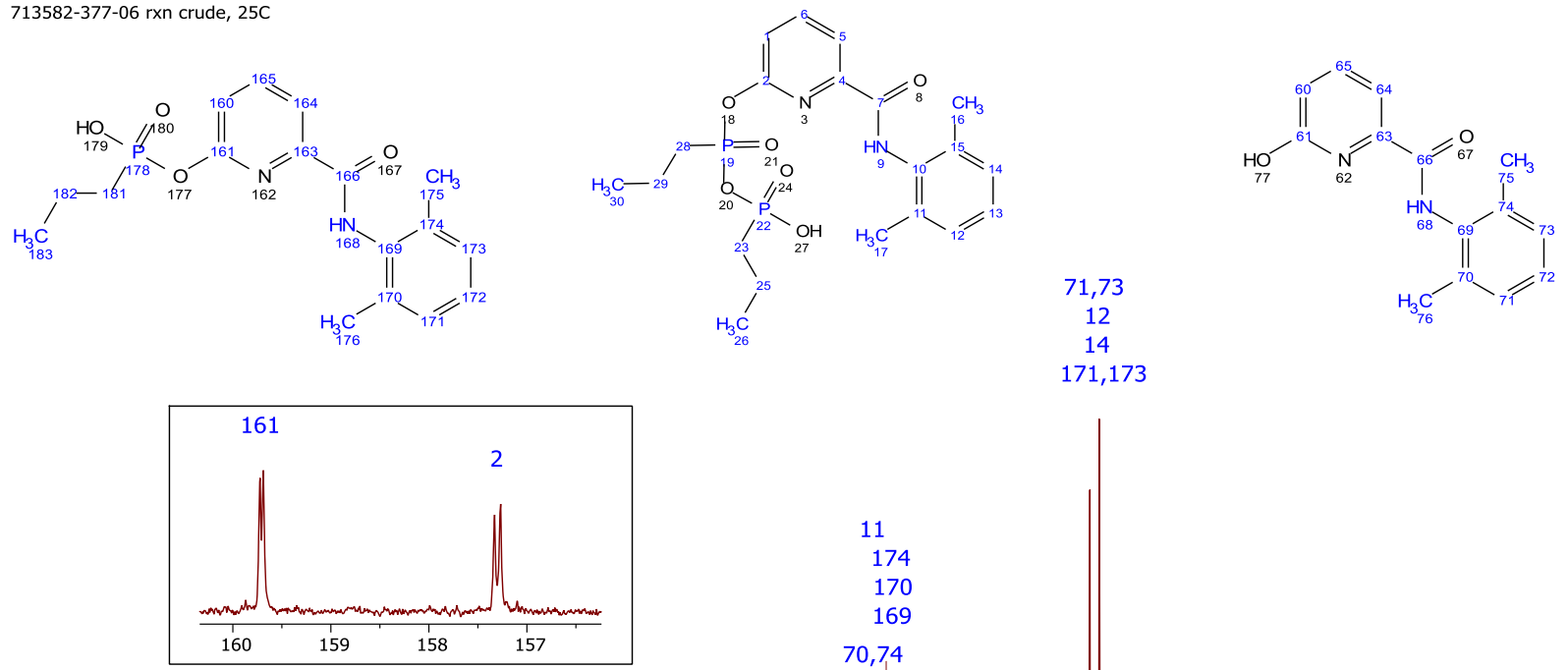

171,173

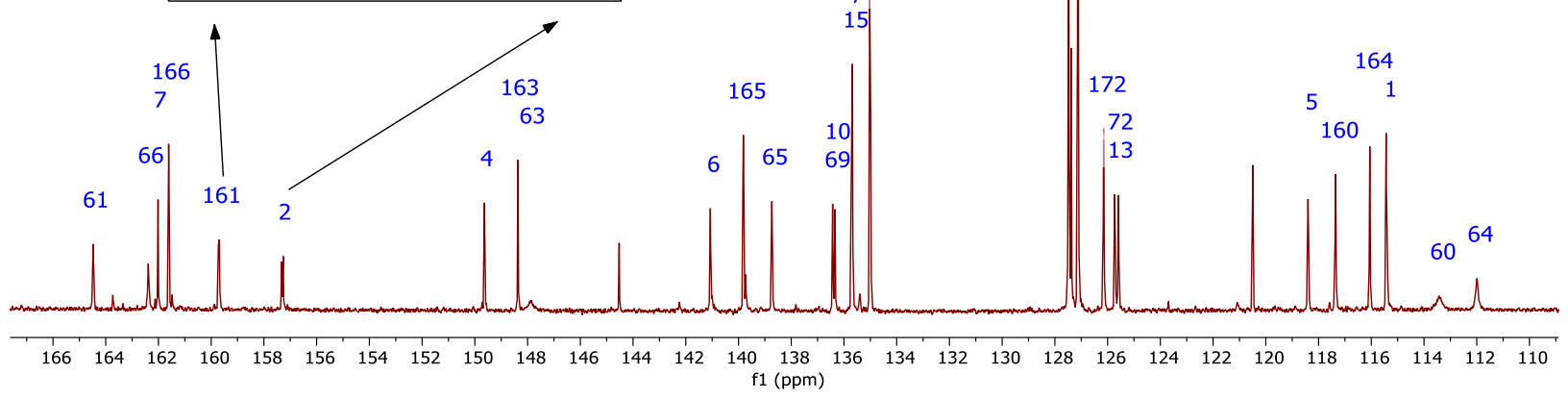

${ }^{13} \mathrm{C}\left\{{ }^{1} \mathrm{H}\right\}$ spectrum $(150 \mathrm{MHz})$ of the crude reaction mixture showing the aromatic region with assignment annotation. Aromatic carbons in ligands $\mathbf{9}$ and $\mathbf{1 0}$ displaying ${ }^{2} J_{\mathrm{CP}}$ couplings are shown in an insert panel. 
00712555-0155_SEG2020-439-440.2.fid

BBFO $600 \mathrm{MHz}, \mathrm{P} 31\{\mathrm{H} 1\}, 12 / 3 / 2020$

713582-377-06 rxn crude, 25C
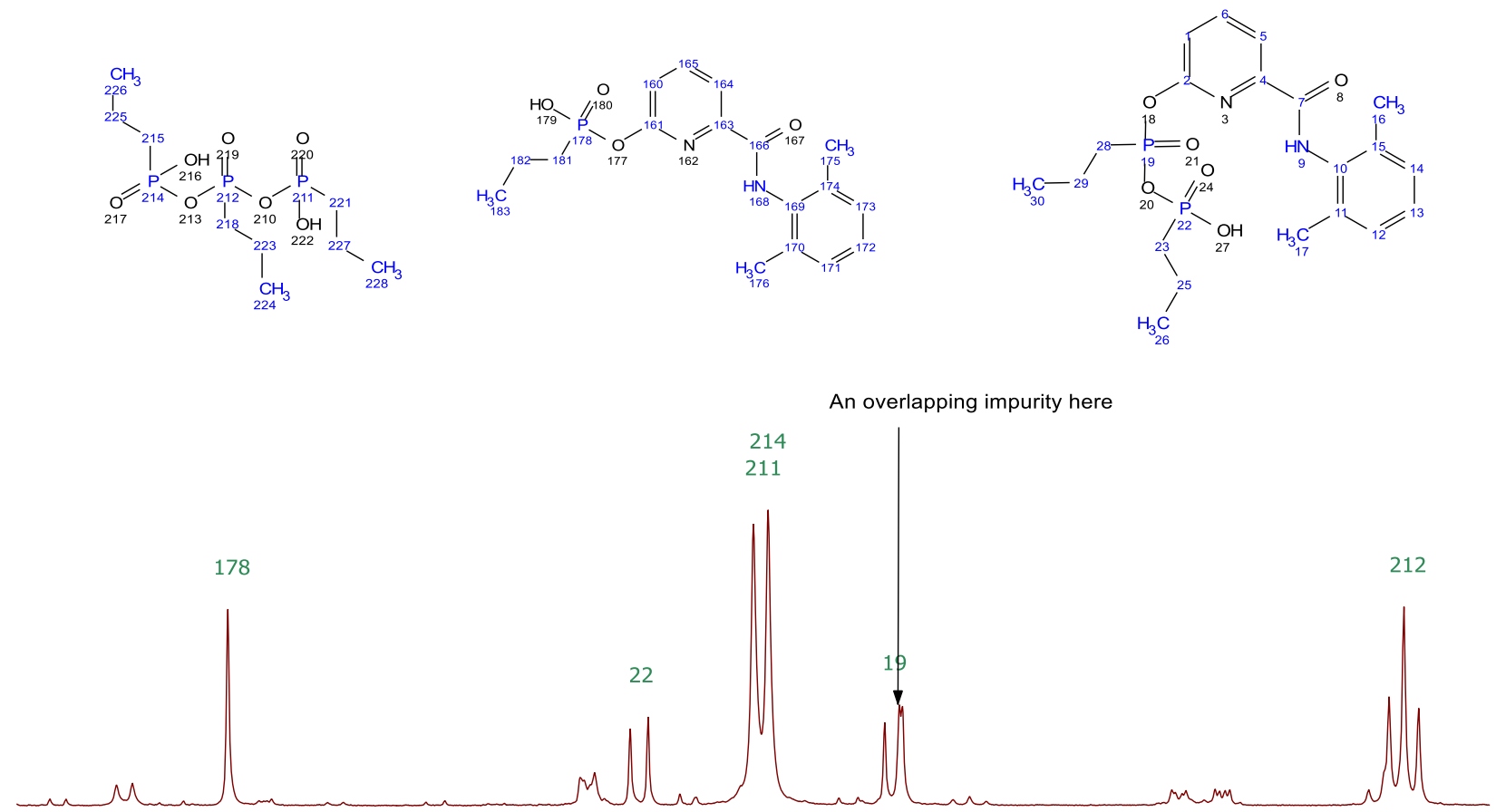

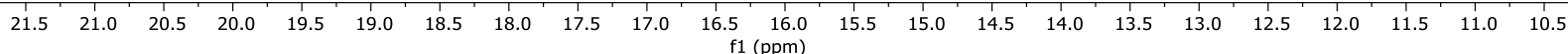

${ }^{31} \mathrm{P}\left\{{ }^{1} \mathrm{H}\right\}$ spectrum $(243 \mathrm{MHz})$ showing assignments of $\mathbf{1 , 9}$, and $\mathbf{1 0 .}$ 


\section{Tabulated data of degradation of 9 and 10 to form 6.}

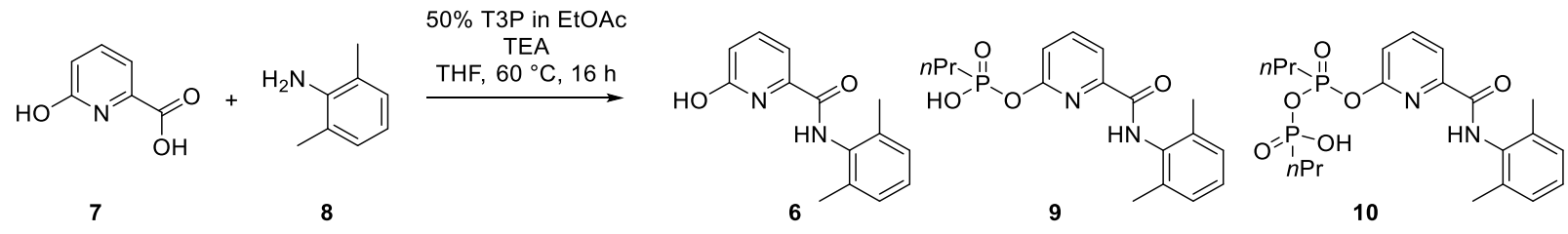

\begin{tabular}{|c|c|c|c|c|c|c|c|c|c|c|c|c|c|c|c|c|}
\hline & \multicolumn{3}{|c|}{ Initial } & \multicolumn{3}{|c|}{$\mathrm{T}=0 \mathrm{~h}$} & \multicolumn{3}{|c|}{$\mathrm{T}=1 \mathrm{~h}$} & \multicolumn{3}{|c|}{$\mathrm{T}=2 \mathrm{~h}$} & \multicolumn{3}{|c|}{$\mathrm{T}=4 \mathrm{~h}$} \\
\hline & & 6 & 9 & 10 & 6 & 9 & 10 & 6 & 9 & 10 & 6 & 9 & 10 & 6 & 9 & $\overline{10}$ \\
\hline \multirow{2}{*}{ pH 1} & $\begin{array}{c}\mathrm{No} \\
\mathrm{MeOH}\end{array}$ & \multirow{8}{*}{46} & \multirow{8}{*}{31} & \multirow{8}{*}{23} & 95 & 2 & 3 & 100 & 0 & 0 & 100 & 0 & 0 & 100 & 0 & 0 \\
\hline & $\begin{array}{c}\text { With } \\
\mathrm{MeOH}\end{array}$ & & & & 71 & 14 & 15 & 99 & 1 & 0 & 99 & 1 & 0 & 100 & 0 & 0 \\
\hline \multirow{2}{*}{$\mathrm{pH} 3$} & $\begin{array}{c}\text { No } \\
\mathrm{MeOH}\end{array}$ & & & & 55 & 27 & 18 & 89 & 9 & 2 & 96 & 3 & 1 & 100 & 0 & 0 \\
\hline & $\begin{array}{c}\text { With } \\
\mathrm{MeOH}\end{array}$ & & & & 56 & 25 & 19 & 86 & 10 & 4 & 94 & 6 & 0 & 100 & 0 & 0 \\
\hline \multirow{2}{*}{ pH 5} & $\begin{array}{c}\mathrm{No} \\
\mathrm{MeOH}\end{array}$ & & & & 54 & 28 & 18 & 61 & 32 & 7 & 71 & 27 & 2 & 84 & 16 & 0 \\
\hline & $\begin{array}{c}\text { With } \\
\mathrm{MeOH}\end{array}$ & & & & 54 & 27 & 19 & 75 & 20 & 5 & 87 & 12 & 1 & 97 & 3 & 0 \\
\hline \multirow{2}{*}{$\begin{array}{c}\mathrm{pH} \\
12\end{array}$} & $\begin{array}{c}\mathrm{No} \\
\mathrm{MeOH}\end{array}$ & & & & 52 & 28 & 20 & 53 & 42 & 5 & 54 & 44 & 2 & 54 & 46 & 0 \\
\hline & $\begin{array}{c}\text { With } \\
\mathrm{MeOH}\end{array}$ & & & & 54 & 27 & 19 & 56 & 39 & 5 & 56 & 42 & 2 & 55 & 45 & 0 \\
\hline
\end{tabular}

'Gaussian 16, Revision A.03, M. J. Frisch, G. W. Trucks, H. B. Schlegel, G. E. Scuseria, M. A. Robb, J. R. Cheeseman, G. Scalmani, V. Barone, G. A. Petersson, H. Nakatsuji, X. Li, M. Caricato, A. V. Marenich, J. Bloino, B. G. Janesko, R. Gomperts, B. Mennucci, H. P. Hratchian, J. V. Ortiz, A. F. Izmaylov, J. L. Sonnenberg, D. Williams-Young, F. Ding, F. Lipparini, F. Egidi, J. Goings, B. Peng, A. Petrone, T. Henderson, D. Ranasinghe, V. G. Zakrzewski, J. Gao, N. Rega, G. Zheng, W. Liang, M. Hada, M. Ehara, K. Toyota, R. Fukuda, J. Hasegawa, M. Ishida, T. Nakajima, Y. Honda, O. Kitao, H. Nakai, T. Vreven, K. Throssell, J. A. Montgomery, Jr., J. E. Peralta, F. Ogliaro, M. J. Bearpark, J. J. Heyd, E. N. Brothers, K. N. Kudin, V. N. Staroverov, T. A. Keith, R. Kobayashi, J. Normand, K. Raghavachari, A. P. Rendell, J. C. Burant, S. S. Iyengar, J. Tomasi, M. Cossi, J. M. Millam, M. Klene, C. Adamo, R. Cammi, J. W. Ochterski, R. L. Martin, K. Morokuma, O. Farkas, J. B. Foresman, and D. J. Fox, Gaussian, Inc., Wallingford CT, 2016.

ii NBO 6.0. E. D. Glendening, J. K. Badenhoop, A. E. Reed, J. E. Carpenter, J. A. Bohmann, C. M. Morales, C. R. Landis, and F. Weinhold (Theoretical Chemistry Institute, University of Wisconsin, Madison, WI, 2013); http://nbo6.chem.wisc.edu/ 